\title{
ORNAMEN BALI DALAM DESAIN INTERIOR HOTEL ARI PUTRI
}

I Made Jayadi Waisnawa

FSRD InstitutSeni Indonesia Denpasar

email: dekwi_vijay@yahoo.com

\section{Abstrak}

Masyarakat tradisional Bali dikenal sangat menghargai alam dalam setiap aktivitas kehidupan. Adanya penghormatan ini memberikan inspirasi bagi perkembangan pengetahuan masyarakat Bali. Kreatifitas menghadirkan beberapa motif ornamen khas budaya Bali seperti kekarangan dan pepatran. Motif-motif ornamen banyak mengambil inspirasi dari alam khususnya tanaman yang memiliki karakteristik merambat. Selain inspirasi dari alam, motif-motif ornamen juga mengambil inspirasi dari beberapa cerita mitologi masyarakat Bali.Sebagai warisan budaya, motif ornamen ini seharusnya mampu untuk dikembangkan lebih lanjut dalam rangka melestarikan warisan leluhur. Pengembangan motif ornamen ini dapat dilakukan dengan mendeformasi bentuk asli namun tetap dilandaskan oleh makna aslinya. Sebagai desainer interior, pengembangan motif ornamen khas Bali dihadirkan pada elemen dinding ruang, kain pelapis (furnishing) sofa dan beberapa hiasan pada furniture. Pengembangan pada interior ini diharapkan dapat memberikan inspirasi bagi generasi muda akan kemampuan warisan budaya dalam beradaptasi dengan perkembangan zaman.

Kata kunci: masyarakat Bali, ornament, motif ornament, dan desain interior

\section{Abstract}

Traditional Balinese society is well-known for its being so appreciative with nature in every activity the people conduct. This respect to nature gives inspiration to the knowledge development of Balinese society. Their creativity enable them to produce some special Balinese ornament motives such as kekarangan and pepatran. These ornament motives are inspired a lot by nature, especially from some creeping plants. Besides being inspired from nature, these motives are also inspired by some Balinese myths. As cultural heritage, these ornament motives should be able to be further developed in order to preserve them. The development of these motives can be conducted by deforming the original motives without leaving out the original phylosophical meanings. As an interior designer, the researcher presents the development of the Balinese ornament motives on the elements of the room walls, the sofa furnishing, and some of the motives and accesories on the furniture. The development on the interior is hoped to be able to notify young generation on the ability of Balinese cultural heritage of dapting to the evolving era.

Keywords: Balinese society, ornament, ornament motives, and interior design 


\section{PENDAHULUAN}

Alam dengan berbagai kehidupan seperti pohon, air, udara dan binatang menjadi sesuatu yang sangat berharga bagi masyarakat tradisional Bali. Penghargaan tersebut tercerminkan melalui penerapan konsep tata letak lingkungan rumah tinggal, pemukiman dan tempat suci. Selain sebagai konsep tata letak lingkungan, alam juga menjadi inspirasi masyarakat tradisional dalam berkesenian khususnya ragam hias atau ornamen tradisional Bali. Dalam lingkungan rumah tinggal, alam mendapatkan tempat khusus yang disebut dengan natah dan karang tuang. Beberapa upacara agama masyarakat Bali juga mencerminkan akan tingginya penghargaan terhadap alam. Seperti halnya tumpek bubuh yang merupakan tradisi dimana manusia memohon kepada Tuhan agar melalui tumbuhan diberikan kemakmuran dan keselamatan serta terhindar dari bencana alam. Natah merupakan sebuah area kosong yang terletak di tengahtengah pekarangan rumah tinggal. Selain memiliki filosofi dan makna sakral, area ini memiliki makna profan sebagai area penerimaan tamu pada saat menyelenggarakan upacara adat maupun agama. Jika dihubungkan dengan lingkungan, area ini sangat berperan dalam sirkulasi udara untuk bangunanbangunan yang terdapat di sekitarnya. Karang tuang memiliki makna yang hampir sama dengan natah, hanya letak dan filosofinya yang berbeda. Karang tuang merupakan area kosong yang terletak pada arah tenggara dan barat laut pada lingkungan rumah tradisional Bali. Area yang terletak pada arah tenggara oleh masyarakat tradisional Bali difungsikan sebagai kandang ternak dan kebun sayuran sedangkan area yang terletak pada arah barat laut difungsikan sebaga taman dan biasanya terdapat sebuah bangunan suci yang dipercaya mampu menjaga lingkungan rumah tinggal.

Dalam berkesenian masyarakat tradisional Bali juga menjadikan alam sebagai inspirasi saat berkarya. Bentuk-bentuk ragam hias khas Bali merupakan hasil stilirisasi dari beberapa tanaman yang memiliki peranan penting dalam aktifitas kehidupan. Mulai dari daun, bunga sampai buah teraplikasi kedalam sebuah karya seni. Tanaman yang memiliki karakteristik meramba terimajinasikan menjadi sulur-sulur dengan beberpa penyederhanaan bentuk. Beberapa hewan seperti burung, singa dan gajah disederhanakan melalui bentuk kepala. Selain tanaman dan binatang, makhluk-makhluk yang ada dalam mitolog masyarakat Hindu di Bali juga tertuang ke dalam karya seni seperti naga, singa bersayap dan raksasa.Keseluruhan imajinasi karya seni dalam ragam hias tersebut tidak semata-mata hadir melainkan melalui proses pemikiran sehingga mampu mencerminkan makna antara hubungan manusia dengan alam. Aplikasi pada arsitektur dengan makna yang terkandung di dalamnya memberikan pemahaman untuk dapat menghargai alam semesta. Simbolisasi dalam ragam hias pada arsitektur tidak hanya memberikan kesadaran untuk menghargai alam nyata (sekala) namun juga menghargai alam yang tidak dapat dijelaskan oleh logika (niskala) karena hal tersebut ada dalam kehidupan manusia. Mitologi masyarakat Hindu di Bali yang juga hadir dalam ragam hias merupakan sebuah usaha untuk menggambarkan harmonisasi kehidupan manusia dan alam baik nyata (sekala) maupun alam tidak nyata (niskala).

Kreatifitas dalam bidang seni yang tertuang melalui ragam hias menjadi sangat penting dalam perkembangan jaman saat ini baik sebagai warisan budaya maupun sarana pembelajaran terhadap generasi muda melalui makna yang terkandung di dalamnya. Bentuk-bentuk ragam hias yang mengambil inspirasi dari alam dengan makna kehidupan dapat dilihat langsung secara visual sehingga akan sangat mudah untuk dipelajari. Kreatifitas seperti inilah yang seharusnya dikembangkan dalam usaha melestarikan budaya lokal khususnya Bali. Kemampuan manusia dalam mengimajinasikan alam telah tertuang dalam bentuk ragam hias yang menjadi ciri khas dan dikenal oleh masyarakat Bali khususnya. Perkembangan jaman yang begitu pesat seharusnya diikuti oleh pengembangan kreatifitas pada warisan budaya, tentunya tanpa menghilangkan makna yang terkandung di dalamnya.

\section{PENGEMBANGAN RAGAM HIAS BALI}

Secara mendasar ragam hias Bali merupakan hasil pengembangan ragam hias yang datang dari daerah Jawa. Ragam hias ini diperkirakan sampai karena beberapa faktor seperti datangnya kerajaan Hindu Jawa ke Bali dan datangnya orang-orang Jawa ke Bali dengan tujuan penyebaran agama. Seiring perkembangannya ragam hias Bali membentuk sendiri ciri khasnya sehingga menjadikannya berbeda dengan ragam hias daerah lain yang ada di Indonesia.

Daun menjadi bentuk yang paling dominan hadir dalam ragam hias karena karakternya yang sangat dekat dengan alam dan pertumbuhan. Terdapat beberapa jenis ragam hias yang mengambil inspirasi dari daun seperti patra bun-bunan, patra pid-pid, patra samblung, patra pae, patra ganggong dan patra sulur. Dari beberapa jenis ragam hias tersebut akan diambil bentuk-bentuk yang dianggap menjadi ciri khas ragam hias daerah Bali.

Pada Gambar 1 dapat dilihat bentuk daun hadir dengan tiga buah lekukan pada kedua sisinya. Lekukan pada pangkal daun dibuat dengan bentuk mirip daun muda pada tanaman paku atau yang biasa disebut dengan util. 


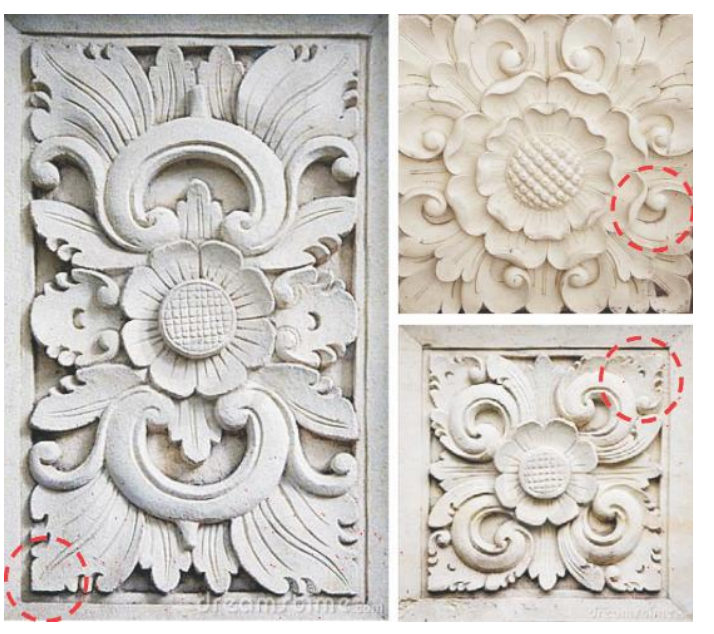

Gambar 1. Bentuk bunga dan daun ragam hias Bali Sumber : reproduksi penulis

Untuk menyambung daun dipergunakan bentuk sulur-sulur dengan ujung melengkung membentuk lingkaran.

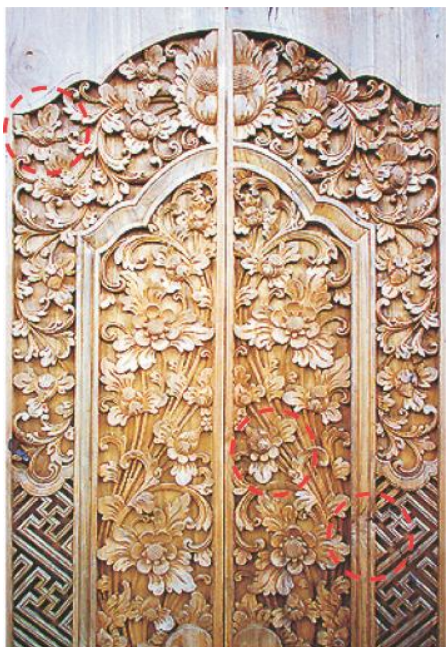

Gambar 2. Ragam hias pada pintu Sumber : reproduksi penulis

Meskipun terdapat beberapa bentuk khas yang dimiliki ragam hias Bali, dalam pengembangan kali ini akan diambil dua bentuk yang dianggap mampu berkolaborasi dengan pola-pola modern.

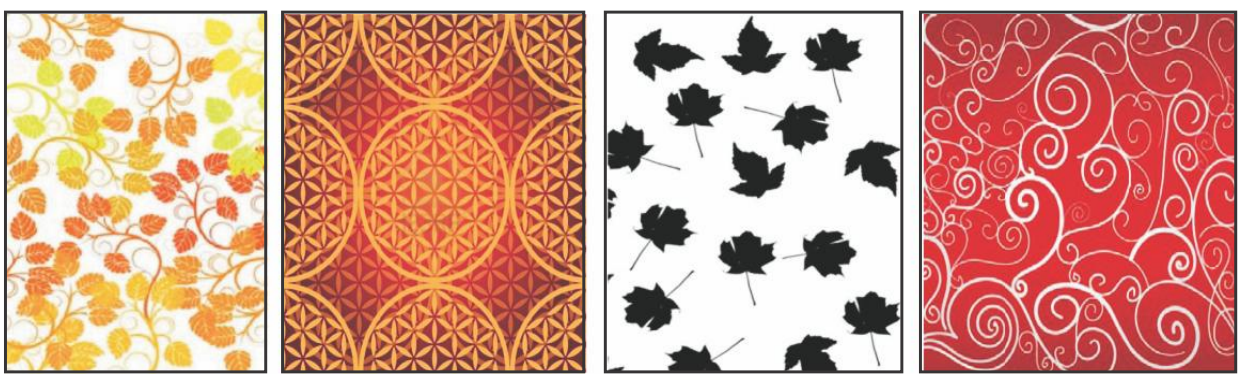

Gambar 3. Motif-motif daun bergaya modern

Sumber : reproduksi penuli

Gambar diatas merupakan beberapa contoh yang akan digabungkan dengan dua bentuk yang menjadi ciri khas ragam hias Bali. Terdapat bentuk daun dengan ranting-ranting dan warna yang terang sehingga pola terkesan ringan. Perpaduan dua bentuk lingkaran dengan teknik gradasi warna sehingga terlihat menumpuk namun tetap terkesan sederhana. Daun-daun yang dibiarkan berdiri sendiri pada bidang dengan hanya memberikan dua warna yaitu hitam dan putih memberikan kesan daun melayang. Kombinasi garis lengkung/kurva berwarna putih dengan latar belakang berwarna merah memberikan kesan semarak pada bidang.

Ragam hias Bali yang biasanya difungsikan pada arsitektur dan sarana upacara kini akan dicoba pada elemen interior dan furniture sehingga diharapkan mampu memberikan kesan berbeda terhadap ruang.
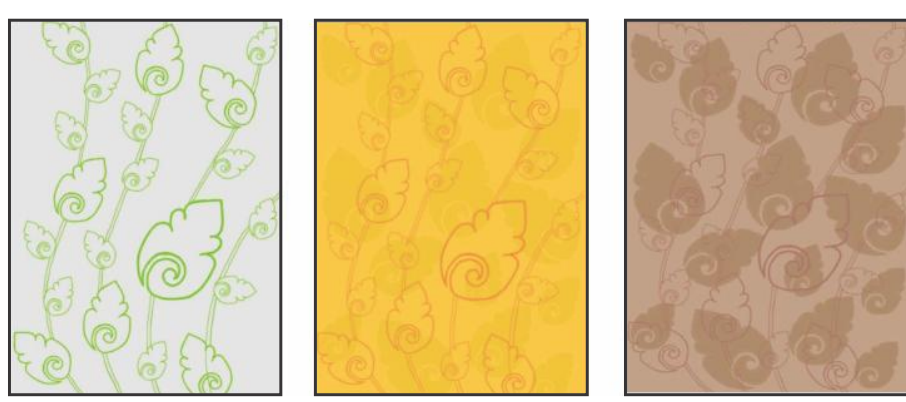

Gambar 4. Pengembangan motif daun dan warna Sumber : reproduksi penulis

Warna akan memberikan karakter jika warna tersebut masih asli atau baik, maksudnya disini adalah jika warna sudah mulai luntur, lebih muda atau suram maka karakternyapun akan berubah.

1) Putih berkesan cerah, merangsang, kesucian, murni, jujur, kedamaian dan kehormatan.

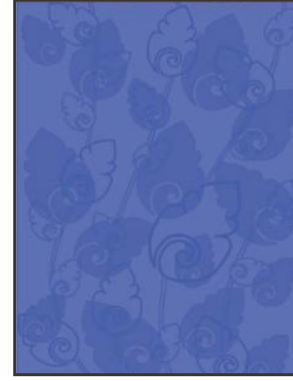


2) Kuning melambangkan kecerahan, kehidupan, kemenangan, kemeriahan, keagungan, kemewahan dan kejayaan

3) Jingga/oranye melambangkan anugrah dan kehangatan.

4) Biru memiliki kesan dingin, jauh, dalam keagungan, keteguhan kecerdasan dan perdamaian.

5) Abu-abu melambangkan ketenangan, bijaksana dan kerendahan hati (Sanyoto, 2009: 46-51)

Bentuk daun dengan berbagai dimensi yang dikombinasikan dengan garis-garis lengkung. Pemakaian warna hijau dengan latar belakang putih memberikan kesan ringan. Pada bagian latar belakang digabungkan beberapa daun namun dengan posisi bebas dan warna yang lebih redup.
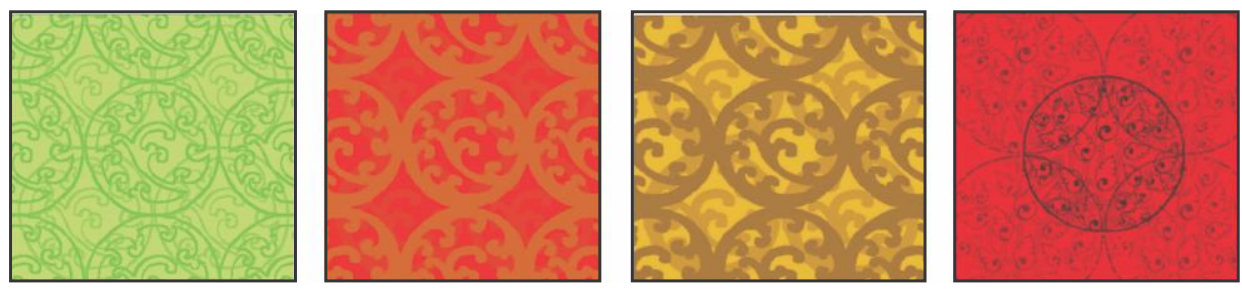

Gambar 4. Pengembangan bentuk lingkaran dan warna Sumber : reproduksi penulis

Rupa bentuk mendominasi lingkungan buatan manusia seperti desain arsitektur dan interior sehingga mampu menghadirkan karakter visual. Lingkaran adalah bentuk yang kompak, egosentris, fokus, kesatuan, kontinuitas da keteraturan bentuk. (Ching, 1996: 103). Satu bentuk dasar berupa lingkaran kemudian digabungkan dengan bentuk-bentuk sulur. Setelah sebuah desain terbentuk makan kembali dikombinasikan dengan bentuk yang sama dengan teknik repetisi.
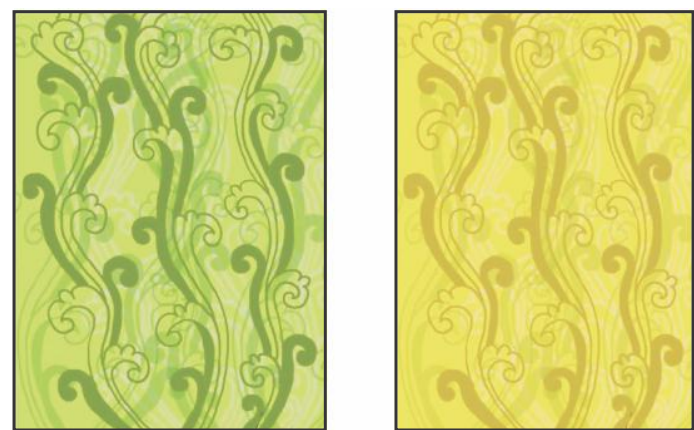

Gambar 5. Pengembangan bentuk sulur dan warna Sumber : reproduksi penulis
Bentuk kurva banyak dijumpai di alam, seperti bentuk tubuh manusia apabila dikombinasikan dengan bentuk-bentuk geometri yang lain akan memberikan karakter (Kusmiati, 2004:70). Bentuk sulur ragam hias Bali yang biasanya melingkar, kini diposisikan berorientasi ke atas dengan permainan motif yang lebih tipis pada bagian belakang sebagai latar.

Selain bentuk dua dimensi, terdapat pengembangan dalam bentuk tiga dimensi. Pengembangan ini dilakukan pada elemen pemisah ruang sehingga lebih menyerupai kisi-kisi. Dinding menjadi tidak kaku namun memberikan kesan riangan dan luas.Dalam ragam hias/ornamen tradisional Bali yang terdapat pada setiap bagian bangunan (dasar, dinding dan atap) merupakan bentuk dasar dari flora dan fauna yang terdapat di alam. Beberapa flora dan fauna yang dipilih berdasarkan cerita filosofi agama masyarakat Bali yang memiliki makna simbolis dan edukatif. Aplikasinya merupakan ekspresi dari pembuat sehingga ada yang memiliki bentuk menyerupai asli dan ada yang disederhanakan. Salah satu contoh adalah bentuk fauna gajah pada dasar bangunan yang hanya dibuat dengan menonjolkan kombinasi bentuk persegi, namun ada yang membuat dengan lekukan-lekukan yang bersifat realis (Dwijendra, 2009:186-187). Pada dasarnya bentuk-bentuk yang diambil lebih disederhanakan sehingga tidak terkesan memberatkan ruang.

\section{PENGEMBANGAN RAGAM HIAS PADA INTERIOR}

Usaha melestarikan budaya lokal terkesan mendapatkan hambatan karena permasalahan filosofi dan makna yang terkandung di dalamnya. Hal ini menyebabkan aplikasi budaya lokal khususnya ragam hias pada arsitektur terbatas pada fisik luar bangunan. Bahkan bentuk-bentuk yang sering ditemukan memiliki kesamaan sehingga tidak adanya keberanian dalam pengembangannya. Jika dipahami secara mendalam bahwa ragam hias merupakan sebuah penghargaan manusia terhadap alam sehingga menginspirasi seniman dalam berkreatifitas. Seperti apa yang dikatakan oleh Gilles Deleuze dan Feliz Guattari pada prinsip deteretorialisasi yaitu setiap unsur yang dibentuk oleh teretorial-teretorial dengan makna kebudayaan harus dapat berkembang dan mengantisipasi perugahan jaman.

Dengan kemajuan ilmu pengetahuan dan semakin dipahaminya makna yang terkandung di dalam ragam hias seharusnya pengembangan bentuk, pola dan warna tidak terbatas. Pengembangan yang dilakukan justru didasarkan oleh makna dalam ragam hias itu sendiri. Dengan makna, pengembangan bisa dilakukan lebih jauh dari fisik luar bangunan menuju fisik bagian dalam bangunan. Pada interior, pengembangan bisa dilakukan pada elemen pembentuk ruang, furniture maupun aksesori. Dengan adanya pengembangan ragam hias Bali pada interior diharapkan kesatuan konsep antara arsitektur dan interior dapat tercapai. 


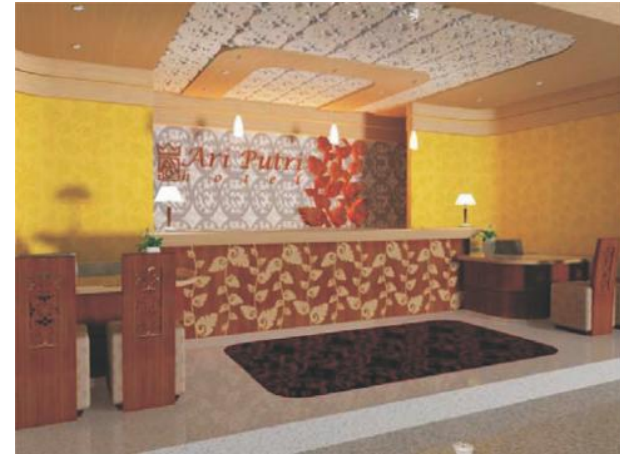

Gambar 6. Aplikasi pada ruang lobby Sumber : reproduksi penulis

Pemakaian material sintetis dalam bentuk karpet memungkinkan untuk menghadirkan kreasi bentuk-bentuk ragam hias Bali. Makna kekuatan dihadirkan melalui batu koral yang terdapat pada lantai kaca, desain ini mengambil makna alamiah batu yang memiliki sifat keras dan lantai kaca merupakan aplikas material yang bersifat lembut namun memiliki daya tahan yang baik. Selain itu warna hitam dan merah dari karpet merupakan simbol kekuatan menurut filosofi Hindu. Bentuk-bentuk ragam hias tradisional Bali dideformasi ke dalam bentuk lingkaran sehingga memberikan kesatuan dengan konsep. Secara keseluruhan ruang lobby pembagian area utama, madya dan nista dibedakan atas warna material granit dan elevasi lantai. Hal ini merupakan desain untuk menghubungkan konsep Tri Angga yang memiliki susunan secara vertikal. Susunan area dengan tone terang menuju gelap merupakan usaha untuk menjadikan area utama sebagai pusat perhatian dan simbol filosofi yang mencerminkan area utama adalah stana para dewa.

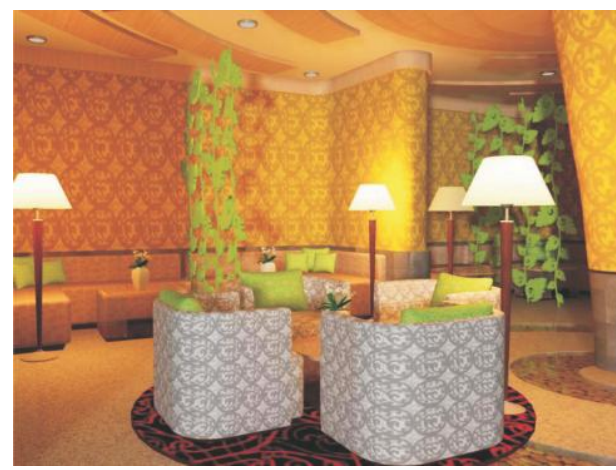

Gambar 7. Aplikasi pada ruang tunggu Sumber : reproduksi penulis
Pada area tunggu lobby simbol-simbol dengan makna kehidupan diaplikasikan pada penyekat ruang duduk. Bentuk daun bersulur yang dibuat dengan arah berbeda memberikan makna kehidupan yang selalu diawali dengan kelahiran dan diakhiri dengan kematian. Pada kamar dengan tipe single ini elemen dinding hadir dengan perpaduan material cermin dan kayu. Motif daun yang diambil dari ragam hias tradisional Bali menjadi sebuah vocal point dalam ruang dengan dimensinya yang cukup besar pada dinding belakang tempat tidur.

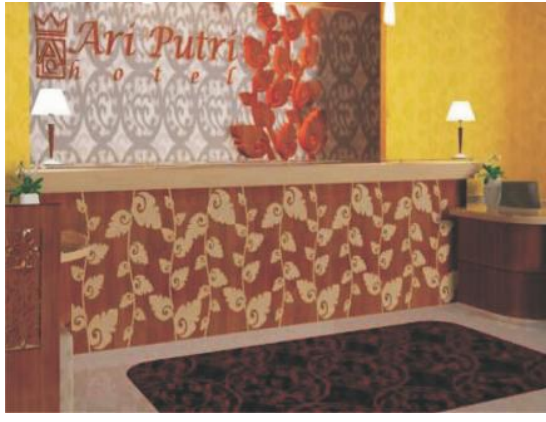

Gambar 9. Aplikasi pada meja tamu Sumber : reproduksi penulis

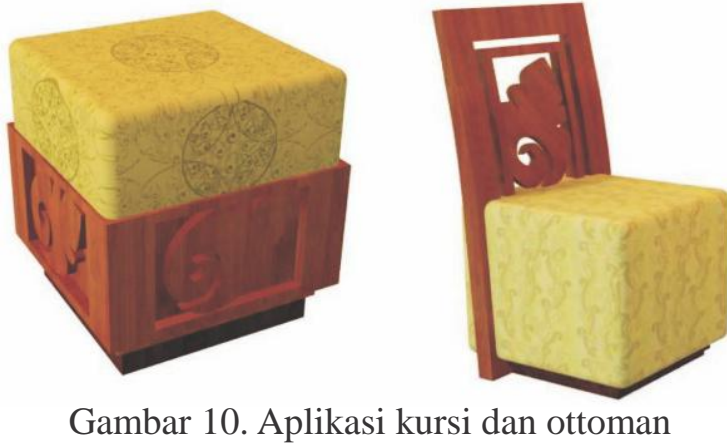

Sumber : reproduksi penulis

\section{PENUTUP}

Ragam hias sebagai hasil budi dan daya manusia merupakan sebuah penghargaan terhadap alam. Konsep Tri Loka yang membagi alam semesta menjadi tiga bagian tergambar dalam setiap kreatifitas ragam hias. Dengan berdasarkan terhadap makna yang terkandung di dalamnya kreasi ragam hias mampu dikembangkan lebih jauh untuk mampu lestari di setiap jamannya. Pengembangan dalam desain interior merupakan salah satu dari usaha melestarikan budaya khususnya Bali. Desain-desain yang hadir dalam interior 
dalam bentuk wallpaper, furnishing sofa dan furniture akan menghadirkan suasana yang kental dengan budaya lokal. keseragaman konsep antara arsitektur dan interior menjadi satu kesatuan yang akan menyadarkan masyarakat bahwa budaya lokal mampu berjalan beriringan dengan perkembangan jamannya.

\section{DAFTAR PUSTAKA}

Ching, Francis. D. K. 1996. Interior Design Illustrated, terjemahan Paul Hanoto Adjie. Jakarta: Erlangga

Dwijendra. N.K. Acwin. 2009. Arsitektur Rumah Tradisional Bali, Denpasar: Udayana University Press dan CV Bali Media Adhikarya.

Dwijendra. N.K. Acwin. 2009. Arsitektur dan kebudayaan Bali Kuno, Denpasar: Udayana University Press dan CV Bali Media Adhikarya,

Kusmiati, Artini. 2004.Dimensi Estetika pada Karya Arsitektur dan Desain. Jakarta: Djambatan.

Neufert, Ernst. 1996. Architec data atau Data Arsitek. Terjemahan Sunarto Tjahjadi. Jakarta: Erlangga

Sanyoto, Sadjiman Ebdi. 2010. Nirmana. Yogyakarta:Jalasutra. 
